\title{
Education for the Sustainable Development and Corporate Social Responsibility in Higher Education Institutions (HEIs): Evidence from Greece
}

\author{
Anastasios Sepetis ${ }^{1}$, Aspasia Goula1, Niki Kyriakidou², Fotios Rizos ${ }^{3}$, Marilena G. Sanida4 \\ ${ }^{1}$ Postgraduate Program in Health and Social Care Management, Department of Business Administration, University of West Attica, \\ Egaleo, Greece \\ ${ }^{2}$ Leeds Business School, Leed, U.K. \\ ${ }^{3} \mathrm{MSc}$ in Economic and Health Management, University Of Piraeus, Piraeus, Greece \\ ${ }^{4}$ Department of Maritime Studies, University of Piraeus, Piraeus, Greece \\ Email: ^tsepet@yahoo.com
}

How to cite this paper: Sepetis, A., Goula, A., Kyriakidou, N., Rizos, F., \& Sanida, M. G. (2020). Education for the Sustainable Development and Corporate Social Responsibility in Higher Education Institutions (HEIs): Evidence from Greece. Journal of Human Resource and Sustainability Studies, 8, 86-106. https://doi.org/10.4236/jhrss.2020.82006

Received: April 24, 2020

Accepted: May 10, 2020

Published: May 13, 2020

Copyright $\odot 2020$ by author(s) and Scientific Research Publishing Inc. This work is licensed under the Creative Commons Attribution International License (CC BY 4.0).

http://creativecommons.org/licenses/by/4.0/ (c) (i) Open Access

\begin{abstract}
This paper investigates the Education for Sustainable Development in international and Greek Universities. It further aims to investigate how Greek students comprehend the Sustainable Development (SD) issues and Corporate Social Responsibility (CSR) and support, as future managers, its added value concerning the environmental, social and corporate governance management in the Greek Business Community. For this purpose, a literature review and a field research among Greek Higher Educational Institutions (HEIs) students has been conducted. The field research and other relevant researches conclude that the Greek HEIs have followed the international trends and started implementing CSR and Sustainable Development courses in their curriculum. Furthermore, they state that SD and CSR courses are very important for the shaping of a business ethics management, an environmentally friendly behavior and promote the stakeholders interests. Moreover, the field researches find there are strong parallels between the CSR orientation of Greek students and students and managers in other countries. For this reason, Greek Companies could play a significant role at this point, by allowing students to participate in their CSR initiatives. For Greek Higher Educational Institutions (HEIs) and students the SD and CSR, is more than just another scientific subject, as it is a way of completely altering existing way of business management, decision making and market behavior. Therefore, Greek Higher Educational Institutions and students argue that Sustainable Development and
\end{abstract}


CSR are not issues that concern only academic and the corporate world but constitute a greater idea that everyone has to embrace.

\section{Keywords}

Sustainable Development Goals, Education for Sustainable Development, Corporate Social Responsibility (M14), Sustainability (Q56),

Higher Education Institutions (I23)

\section{Introduction}

In September 2015, at the UN headquarters in New York, the international community agreed on a set of 17 Sustainable Development Goals (SDGs), which simultaneously included 169 goals to be achieved by 2030. The SDG framework has a specific objective for education (SDG4-Ensuring inclusive and quality education for all and promoting lifelong learning) and makes explicit reference to higher education, although only this "ensures equal access for all women and men to access and quality technical, vocational and higher education, including university" (SDG4 objective 4.3) (UNESCO, 2018a).

The first comprehensive intervention for the integration of CSR on academic education in Europe was in late 1980s by Professor Mahoney in the form of a comparative study on the teaching of business ethics in the U.S.A., U.K. and Continental Europe (Mahoney, 1990). Following that, numerous articles have been written about education for Sustainable development and CSR education in Higher Education Institutions. The majority of the earliest studies have focused their attention on the economic universities or schools of business. A considerable number of relevant and interrelated specific issues can be found, for instance the relation between marketing and business ethics (Shannon \& Berl, 1997), the sustainability (Weber, 1990; Huckle, 1999; Wheeler et al., 2001) or the evaluation criteria for courses of business ethics (Moon \& Matten, 2004). The success of these actions is being determined by companies, E.U. and by other international bodies and it can be considered, amongst others, a result of the human factor, who has been trained by various training programs in universities (Benn \& Kramar, 2011; Ceulemans et al., 2011) and technological institutes (Wright, 2003; Cantalapiedra et al., 2006; Benn \& Rusinko, 2011). The goal of these earliest programs, often referred to in the international literature as training programs for corporate social responsibility and programs for environmental (and ecological) education and sustainable development, is to prepare employees, future managers and active citizens to improve social, environmental and sustainable business performance (Wright, 2002).

Recently, international organizations, university associations and corporations but also Higher Education Institutions (HEIs), have embraced Education for Sustainable Development (ESD) and CSR management (GUNi, 2017). HEIs have 
also introduced courses concerning CSR and business ethics in their curriculum (UNESCO, 2018b). It appears that these organizations have identified the need and importance of students' knowledge, perceptions and behaviors on social, ethical and environmental issues (Leal Filho et al., 2017, 2018; Lozano et al., 2015, 2019).

Investigating the global literature in depth, it is worth mentioning the strong correlation between the concept of Education for Sustainable Development and CSR. The need of CSR philosophy was emerged mostly after the 70' in order to confront crucial issues, such as environmental scandals, the Climate Change, the Ozone Layer, the protection of biodiversity and to constrain the environmental degradation. Thus, Higher Education Institutions have been introducing subjects concerning Business Ethics, Environmental protection, CSR management, in many academic fields but mostly in Business Administration, firstly at undergraduate level and then at post-graduate level, so as to introduce and promote Sustainable Development Goals.

For these reasons, it is imperative that the Greek students' education on issues regarding CSR and Sustainable Development is crucial so that they have the necessary knowledge, skills and abilities to cope with the changing Greek market needs. Institutions of Higher Education have a very important role to play in sustainable development goals. They should investigate the needs and Greek market trends and try to adapt their curriculum properly so as to provide the necessary knowledge to academics, but also to shape an appropriate behavior and culture on social, environmental and corporate governance responsibility.

However, the question that arises from the above is whether Greek universities have embraced the corresponding actions. The lack of literature on Sustainable Development and Corporate Social Responsibility Policy in Greek Higher Education Institutions, further reinforces the need for research Sustainable Development and CSR in the Greek HEIs.

\section{Education for the Sustainable Development and CSR in the HEIs-Literature Review}

Interdisciplinary researches on the mainstreaming of CSR into European universities, highlight business ethics (Rossouw, 2002), social dimensions of entrepreneurship (Cummins, 1999) and instructional technics of CSR (Cowton \& Cummins, 2003) as priority areas. Research appears to be mainly focused on the scientific field of business ethics in different departments (Van Luijk, 2001; Hartman \& Hartman, 2005). Illustrative examples of such departments are, business administration, mechanical engineering, information technology, architecture, tourism, etc. (Fien, 2002; Wright, 2003; Down, 2006).

Moon \& Matten (2004) suggest that the overall development of education in CSR is not a result of academic research but of other numerous sources. It is also noted that CSR, in the broader sense, is high on the agenda of the learning procedure with the teaching courses for CSR being mostly by the interest of industry rather than the academia (Moon \& Matten, 2004). Furthermore, the integra- 
tion of actions related to sustainable development in the field of education, within the cooperation framework of central public administration with companies, is fairly recent and rather limited (Moon \& Orlitzky, 2011). Another important indicator of the relevance between CSR and schools of Economics and Business Administration is the way of finance of this new scientific field (Ceulemans et al., 2011). Moreover, there has been a debate on whether CSR should be taught as a separate course in the curriculum or if a new program supporting the basis of the concept and content of CSR is to be created (Christensen et al., 2007; Rusinko, 2010). The issue at hand, namely environmental protection awareness, is becoming exceedingly important to students considering the ongoing economic and environmental crisis (Sims \& Felton, 2006; Posch \& Steiner, 2006; Lourdel et al., 2007). In fact, a number of universities around the world have introduced courses in their curriculum regarding environmental protection, environmental ethics, social responsibility and other related subjects. Indicative examples are universities in China (Niu et al., 2010), Russia (Lindroos, 2001), Jamaica (Down, 2006), Austria and Sweden (Anderberg et al., 2009) and Spain (Setó-Pamies et al., 2011). As a result, business ethics have experienced an exceptional boom in the field of Higher Education and similar courses have become more well-known and attractive at both undergraduate and postgraduate levels. Christensen et al. (2007) observed that $42 \%$ of the best MBA programs have incorporated courses on CSR. Similarly, International Schools of Business Administration have begun implementing social and responsible initiatives to educate future leaders, managers and employees in preparation of them facing environmental, social and economic systems throughout their careers and crucial issues around these areas (Deale et al., 2009; Stubbs \& Schapper, 2011).

In the Greek universities, Macris \& Georgakellos (2006) support a new teaching tool in education for sustainable development: ontology-based knowledge networks for environmental training. In the technical universities, Manoliadis (2009) promotes a set of multidisciplinary case studies and support material in order to aid engineering students in understanding the sustainability concepts and how solutions can be developed. Moreover, Sepetis \& Rizos (2011) conducted, for the first time, a research about the promotion of Education in the Sustainable Development in Greek HEIs.

Due to the lack of an institutional framework requiring universities to incorporate sustainable development policies, all best CSR practices and actions have been a result of voluntary initiatives. In sustainable university level, the study of Professor Idowu (2008), examined whether the universities of U.K. are implementing CSR in their business operations. The research shows that most institutions of higher education in the UK are conscious that they owe some responsibility to their stakeholders and are striving to demonstrate this awareness in various ways (Idowu, 2008). A survey by Nejati et al. (2011) shows the effects and benefits of CSR integration for the top 10 universities worldwide. The findings of this research show that world leading universities are committed to their social responsibility and provide sufficient information on most of the core areas of 
corporate social responsibility (CSR) (Nejati et al., 2011). Moreover, research in the Canadian universities by Elliott and Wright in 2013 concluded that while a number of themes emerged, one that was overarching as a general concern and both a barrier and incentive to a more sustainable university was university finances. This in turn is linked with the students through enrolment and recruitment efforts as tuition represents a large proportion of university budgets. Participants believed that students hold the greatest ability of all university stakeholders to promote sustainability on their campuses and when combined with their ability to impact university finances, the possible impact of empowered students to initiate change for more sustainable campuses is great (Elliott \& Wright, 2013). According to Hoover and Harder in the field of sustainable universities, there have been different attempts to conceptualize the characteristics of a sustainable university (Hoover \& Harder, 2014). Thus, a sustainable university entails changing its own mission, redefining curricula, modifying its research programs, integrating new ways of living in their campuses, enhancing social engagement and intervention, and evaluating and announcing these activities Lozano et al. (2015). Moreover, Ceulemans et al. (2011) argue that the topic of Sustainability Reporting (SR) has been approached in a rather fragmented way in the Higher Education for Sustainable Development (HESD) literature, while the scientific field would benefit from more in-depth studies, preferably supplemented by empirical evidence. For this reason, the concept of SR in relation to HESD was until now relatively unclear, and many avenues for further research currently still remain open (Ceulemans et al., 2011). Verhulst \& Lambrechts (2015) presented a conceptual model which links human factors to the sustainable development integration process. The model structures and supports the analysis of this integration process in a higher education institution. It is applied in a specific case study of a Belgian university college. The results indicate that the conceptual model helps to get a profound understanding of human related barriers for integrating sustainable development in higher education, as well as to understand the underlying reasons for these barriers and linkages between them in different stages of the integration process. Another main lesson learned is the importance of continuously supporting ambassadors of sustainable development integration in higher education (Verhulst \& Lambrechts, 2015). A recent study in the Portuguese university students by Aleixo et al. (2018) results suggests that, although aware of the concept of sustainability, the different stakeholders are not familiar with the concept of sustainable higher education institutions. The lack of financial resources due to the decline in funding for higher education and falling numbers of Portuguese university students is perceived as the main barrier to sustainable development in higher education (i.e. practices are still associated with spending financial resources). This research highlights the importance of a conceptual and organizational change in higher education institutions, notably through identifying new sources of financing, more flexible organizational forms, more comprehensive mission statements, more tailored educational offers, life-long 
learning and commitment to internationalization, and more strategic human resource management (Aleixo et al., 2018).

Further research by Karatzoglou (2013) argues that the published ESD research covers a wide range of regions, topics, methodologies, and findings. The prevailing methodological approaches include theoretical and case-study articles. Yet, the former suffer from a rigorous conceptual framework deficiency, while the latter are characterized by their descriptive nature, which can be inspiring and encouraging for future peer efforts but of limited added value to theory development (Karatzoglou, 2013). Across the world, but particularly in Europe, some universities have become leaders in the field with very good practices. But unfortunately, many of those efforts address only one or two of the sustainability domains at HEIs, which continue to foster compartmentalization, instead of a holistic approach (for instance an approach which is inclusive and takes into account inputs and knowledge from different subjects) and a systems thinking approach (Ramos et al., 2015). Lozano et al. (2015) conducted an exploratory literature review to identify the different practices and domains among HEIs within sustainability, and the results revealed that most are focused on education (including curricula, pedagogies, competences and "educating the educators"), followed by campus operations, institutional framework, outreach, and assessment and reporting (Lozano et al., 2015). Recent research by the same authors (in 1997, 2015 updated the theoretical framework) provided a more precise perspective on how sustainability competences can be better developed in class, and how to better develop all the sustainability competences (Lozano et al., 2019). In the following chapter an empirical research will take place, in order to examine the relationship between Sustainable Development and CSR policies in HEIs in Greece.

\section{Education for the Sustainable Development and CSR in the Greek Higher Education Institutions}

Although very little has been done on Sustainable Development Education in Greek universities in relation to the interaction of other international universities in this field, we must admit that Greek higher education institutions are in a unique position to guide the implementation of each Goals for the Sustainable Development from different areas of education, work and action in the Greek business community and Greek society. Greek universities have long been powerful drivers of change both locally, regionally and globally and can support SDGs in thousands of ways in the Greek market. In addition, some Greek higher education institutions have already begun to implement and incorporate the concept of sustainability and CSR management into their universities, institutions, curricula and strategies. Educational authorities have begun to implement and integrate the concept of sustainability into their campuses, institutions, curricula and strategies. Moreover, international, European networks and statements on sustainable development have been created or promoted in existing Greek university networks. The main question that arises is if the introduction 
of these subjects has contributed to social and environmental protection in the Greek Universities and if Greek HEI's students have altered their way of thinking and operating. To reach to a conclusion, a survey was conducted from an indicative sample of Greece HEI's that have implemented courses about Sustainable Development and the CSR.

\subsection{International, European and Greek Conventions and Declarations in the Field of Education for Sustainable Development and CSR Policies in HEIs}

The development of Sustainable Development Education in the HEIs statements has increased both in terms of intensity and scope, as well as the intensification of the interaction between government and university statements. The interaction between university and supranational institutions indicates that in education and research policies sustainability has gained increased attention. This has produced an effect at least in three different ways. In the first place, the parties seem to internationally agree on the universities' role and function in sustainable development. In the second place, the Sustainable Development Education in the HEIs declarations have formed the basis for the adoption of national legislative measures, e.g., in Germany, the UK and the U.S. In the third place, the competition among universities on green campus performance has emerged (Grindsted, 2011).

Today's likewise, universities in Europe and around the world are playing a crucial role in global sustainable development goals. The Association for the Advancement of Sustainability in Higher Education (AASHE) was established in 2005 to "help coordinate and strengthen campus sustainability efforts at regional and national levels, and to serve as the first North American professional association for those interested in advancing campus sustainability". The AASHE also recognizes colleges and universities that have achieved the greatest level of success with green initiatives on-campus and within their surrounding communities. The association gauges these efforts using the Sustainability Tracking, Assessment \& Rating System (STARS), a voluntary system that allows different colleges and universities to report trends and track their sustainability efforts. The European Universities Association (EUA) is dedicated to the international cooperation for sustainable education. Therefore, it is natural that the Association is an active part of the worldwide agenda for achieving the United Nations' Sustainable Development Goals (SDGs). The European Universities contribute to the goals through research and education in a wide array of disciplines that can potentially contribute to a better future. In a complex and developed context like Europe, it is essential that the achievement of the Sustainable Development Goals rests on knowledge, new research, innovation and citizens who are empowered by critical thinking ${ }^{1}$. Recently the Global University Network for innovation (GUNi) presented their latest publication, "implementing the 2030 Agenda at Higher Education In-

${ }^{1}$ Available through the internet: https://eua.eu/issues/24:sustainable-development-goals.html [accessed: 15/8/2019] 
stitutions: Challenges and Responses". The publication focuses on the obstacles that higher education institutions encounter when implementing the Sustainable Development Goals and offers some clues as to what some higher education institutions do to overcome them (GUNi, 2018).

In July 2018, Greece presented its first Voluntary National Review (VNR) at the 2018 UN High-Level Political Forum on Sustainable development (HLPF). This VNR report covers all 17 SDGs ${ }^{2}$ through eight National Priorities for adapting the SDGs to national needs and circumstances, also in line with the above mentioned National Growth Strategy. These eight overarching National Priorities have been defined, through an open dialogue within all government units and with a wide array of stakeholders, and by an in-depth mapping exercise carried out in 2017. One of the eight National Priorities focuses on "Providing high-quality and inclusive education", linked to SDG 4, and covers inter alia all aspects pertaining to ESD. The UNESCO Global Action Plan on ESD (GAP) provides the overall framework for ESD implementation in Greece, linking policies and activities with the UNECE Strategy for ESD, as well as the Mediterranean Strategy on ESD and its endorsed Work Plan ${ }^{3}$. In this context, the Hellenic Ministry of Education is promoting policies and measures at all education levels, for the integration of the basic principles of sustainable development, in line with the overall national education policy, and is implementing concrete interventions at all levels of education, supported by a number of laws and Ministerial Acts, to this end (UNESCO, 2018b). Many national and international declarations to promote sustainability have been developed in the university sustainable education, and many universities have voluntarily signed several initiatives and statements over the last thirty years (Lozano et al., 2015, 2019). However, signing a statement does not imply significant progress in the field of sustainability (Dlouhá et al., 2018).

\subsection{Education for Sustainable Development in Greek Universities}

A very encouraging fact is that Greek HEIs have introduced courses concerning business ethics, Sustainable, Environmental and CSR into their curriculum, following the trends and needs at an international level. The initial step was made mainly by Greek Schools of Economics and Business Administration, which have implemented courses, first in post-graduate level and then in undergraduate level. Some indicative examples of Greek HEIs are demonstrated in the next Table 1.

Taking into account that the role of higher education institutors in Greece is being formed not only from the transportation and transmission of knowledge, but also from the shaping of responsible citizens, it is worth to mention three successful cases of Greek universities that have developed important activities in ${ }^{2}$ Available through the internet: https://sustainabledevelopment.un.org/content/documents/19378Greece_VNR_Greece_2018_pdf_ FINAL_140618.pdf [accessed: 15/8/2019].

${ }^{3}$ https://en.unesco.org/globalactionprogrammeoneducation 
Table 1. Some Greek HEIs courses concerning business ethics, sustainable, environmental and CSR into their curriculum. Source: owns elaboration.

\begin{tabular}{|c|c|c|c|}
\hline Department & HEI & Course & Educational level \\
\hline Business Administration & T.E.I. of Central Macedonia & Business Ethics and CSR & undergraduate \\
\hline Business Administration & $\begin{array}{l}\text { Eastern Macedonia and Thrace } \\
\text { Institute of Technology }\end{array}$ & CSR & undergraduate \\
\hline \multirow{2}{*}{ Business Administration } & \multirow{2}{*}{ University of West Attica } & Business Ethics and CSR & undergraduate \\
\hline & & Sustainable Management and Public Health & undergraduate \\
\hline Business Administration & University of Piraeus & Business Ethics & undergraduate \\
\hline $\begin{array}{l}\text { Marketing and Communication of } \mathrm{New} \\
\text { Technologies }\end{array}$ & Economic University of Athens & CSR & postgraduate \\
\hline Human Resources Management & Economic University of Athens & Internal Communication and CSR & postgraduate \\
\hline Accounting and Finance & University of Macedonia & Action Plan for the Development of CSR", & undergraduate \\
\hline Marketing and Operations Marketing & University of Macedonia & CSR & undergraduate \\
\hline Communications, Media and Culture & Panteion University & $\begin{array}{l}\text { Social Issues and Business Practices" along } \\
\text { with "Business Ethics" }\end{array}$ & undergraduate \\
\hline Accounting and Finance & Economic University of Athens & Business Ethics & undergraduate \\
\hline Marine and Business Studies & Aegean University & Business Ethics & undergraduate \\
\hline School of Chemical Engineering & $\begin{array}{l}\text { The National Technical University } \\
\text { of Athens }\end{array}$ & Environment and Sustainable Development & undergraduate \\
\hline School of Economics & Aristotle University of Thessalonica & $\begin{array}{l}\text { Business and society: Corporate Social } \\
\text { Responsibility }\end{array}$ & undergraduate \\
\hline Civil Engineering & Aristolte University of Thessalonica & $\begin{array}{l}\text { Environmental Protection and Sustainable } \\
\text { Development }\end{array}$ & postgraduate \\
\hline International and European Studies & Panteion University & $\begin{array}{l}\text { Environmental Governance and Sustainable } \\
\text { Development }\end{array}$ & postgraduate \\
\hline Environment & Aegean University & $\begin{array}{l}\text { MESPOM is an Erasmus Mundus Joint Master } \\
\text { Degree in Environmental Sciences, Policy and } \\
\text { Management }\end{array}$ & $\begin{array}{l}\text { interdepartmental } \\
\text { postgraduate }\end{array}$ \\
\hline Department of Maritime Studies & University of Pireaus & $\begin{array}{l}\text { MSc: Sustainability and Quality in Marine } \\
\text { Industry }\end{array}$ & postgraduate \\
\hline School of Science and Technology & International Hellenic University & $\begin{array}{l}\text { MSc in Environmental Management and } \\
\text { Sustainability }\end{array}$ & postgraduate \\
\hline
\end{tabular}

programs of non-formal social and environmental education and have integrated the environmental component in their internal practices. These initiatives can be considered of high importance, because they contribute extensively in the achievement of this broader goal. The University of Macedonia ${ }^{4}$, is the first university in Greece and one of the few in Europe that has designed and implemented an Environmental Management System and Control, based on the European standard EMAS 5 . In the NTU of Athens ${ }^{6}$ the Environmental Economics ${ }^{4}$ Available through the internet: https://www.uom.gr/7909-grafeio-periballontos-pamak-emas [accessed: 15/8/2019].

${ }^{5}$ Available through the internet: Performed in the framework of the program EMAS-EDIN/LIFE02 (2002-2005).

${ }^{6}$ Available through the internet

https://www.researchgate.net/lab/Environmental-Economics-and-Sustainability-Unit-Konstantin-G-Arav ossis nmental-economics-and-sustainability-unit-esu?set_language=en [accessed: 15/8/2019]. 
and Sustainability Unit (ESU) focuses mainly in supporting-on a research and academic level-subjects related to Sustainable Development and Sustainable Production and Consumption. The Aegean University is one of the few universities in Greece that has the privilege of an independent Environmental Department. The laboratory for Environmental Policy \& Strategic Environmental Management was established in $2002^{7}$. The research undertaken by the Lab's personnel focuses on applied environmental policy \& sociology and on the green management of industries and organizations, it supports activities for the development and implementation of the environmental strategies of the University and has set as target "The greening" of the Aegean University ${ }^{8}$. Thus, it has developed a series of eco-friendly actions which are in progress in Mytilini and have been conducted in collaboration with other institutions. The case of the Aegean University proves that practices for environmental management can be developed easily beyond its environmental certification, even in a semi-formal way. The Social Administration Research Laboratory (SARL) ${ }^{9}$, a research initiative introduced by the Social Policy Unit in the Department of Business Administration at the University of West Attica, is mainly working on social and sustainable development issues and on the ways in which society and business community responds to those issues. The International Centre for Research on the Environment and the Economy (ICRE8) $)^{10}$ is a nonprofit private Research Centre dedicated to interdisciplinary research on sustainable development and management of the Environment, Energy, Economy, Eco-innovations and their electronic versions (hence E8). The overarching goal of the Centre is to promote the understanding and implementation of Sustainable Development, as the only non-self-destructive path of socio-economic development. The ReSEES ${ }^{11}$ laboratory in the AEUB University is the outcome of the evolution of the Research Team on Socio-Economic and Environmental Sustainability. In the University of Athens the Political Economy of Sustainable Development Lab (PESD) ${ }^{12}$ is in the academic field of Sustainable Development. The Greek SDSN ${ }^{13}$ has been included in the SDSN network and is co-hosted by ICRE8: International Center for Research on the Environment and the Economy and the Political Economy of Sustainable Development Lab.

\subsection{A Research in the CSR in Business Education in the Greek Universities}

The research has been presented first time in the "ENVECON 2014" under ${ }^{7}$ Available through the internet:

https://www.env.aegean.gr/research/research-laboratories/laboratory-for-environmental-policy-stra tegic-envir-management/ [accessed: 15/8/2019].

${ }^{8}$ Available through the internet:

https://www.env.aegean.gr/erevna/ergasthria/ergasthrio-epixeirisiakis-perib-politikis-diaxeirisis/[accessed: $15 / 8 / 2019]$.

${ }^{9}$ Available through the internet: https://sarl.uniwa.gr/en/homepage/ [accessed: 15/8/2019].

${ }^{10}$ Available through the internet: http://www.icre8.eu/about-icre8 [accessed: 15/8/2019].

${ }^{11}$ Available through the internet: https://www.dept.aueb.gr/en/ReSEES/content/about [accessed: 15/8/2019].

${ }^{12}$ Available through the internet: http://pesd.econ.uoa.gr/description [accessed: 15/8/2019].

${ }^{13}$ Available through the internet: http://www.unsdsn.gr/sdsn-greece [accessed: 15/8/2019]. 
"Corporate social responsibility and environmental management policies in higher education" by Sepetis and Rizos and took place during 2014 from various Schools of Business Administration of the Greek Higher Educational Institutions. Our sample though was mainly from the Technological Educational Institution (TEI) of Athens and the University of Piraeus (Sepetis \& Rizos, 2014). The program used for data processing was the statistical program SPSS17.0 and the analysis presented below used the descriptive statistics. The survey involved 220 students, of which 76 individuals were male (34.5\%) and 144 were female (65.5\%) (Table 2) (Figures 1-8).

Some of the limitations of the survey were the small sample and the few participated HEI. Mainly, it involved two Greek Higher Education Institutions, both in Business Administration area. In the near future, the survey will be extended in more Greek HEI, so that more reliable data and results will be derived, presenting the actual condition in Greece. Moreover, it will investigate the proportion of students that are willing to get employed in organizations that perform CSR actions, conduct sustainability reports or CSR reports. One final field of investigation is whether students will prefer postgraduate programs about CSR and if they believe that they are going to be value-added in their business career. The encouraging fact is that CSR is well-accepted to both students and Greek HEI and is seen as an idea and philosophy whose time has come.

\section{Research Findings and Discussion}

The first CSR research in Business Education in the Greek University was in 2003 by Walker and co-authors, entitled: "An investigation of CSR orientations among Greek University students". In this paper the researcher found that there are strong parallels between the CSR orientation of Greek students and managers in other countries, suggesting that culture may have little bearing on the corporate social responsibility orientations. The findings, in this sense, belie some of the stereotypical images of Greek culture and business practice in Greece (Walker et al., 2003).

Almost ten years since this research for CSR in Greek universities, the research of Sepetis \& Rizos (2014) concluded that Greek students in the Greek business schools have knowledge of CSR at a relative level with European Universities or other international universities. According to this research regarding the question, if Greek students are familiar with the term of CSR, $87 \%$ answered positively, while only $13 \%$ responded negatively. Also, $40 \%$ of them knew the meaning of CSR from their educational institution. These findings are particularly interesting as students seemed to already have a first contact of this new way of business operation and Greek HEIs have contributed to this fact by introducing courses on CSR. It is noteworthy that regarding the concept of CSR, $32.4 \%$ of the Greek students understand CSR as a matter of Corporate Responsibility, 23\% of environmental management issues and less of charity and legal issues. Furthermore, $45 \%$ of the sample believes that CSR is one of the most important subjects 
Table 2. Research has been presented first time in the "ENVECON 2014" under Corporate social responsibility and environmental management policies in higher education by Sepetis and Rizos Source: owns elaboration.

Figure 1: To the question, if the students are familiar with the term of CSR the answers are very impressive, as $87 \%$ answered Yes and only $13 \%$ answered No.

Figure 2: To the question, how did students become familiar with the term of CSR, $40 \%$ of the students responded that they became familiar though the educational area

Figure 3: To the question, which answer corresponds better to the meaning of CSR, over $30 \%$ of the students responded Responsibility to Society.

Figure 4: Regarding what Corporate Social Responsibility is all about, around $20 \%$ of the students answered Business and Organizations.
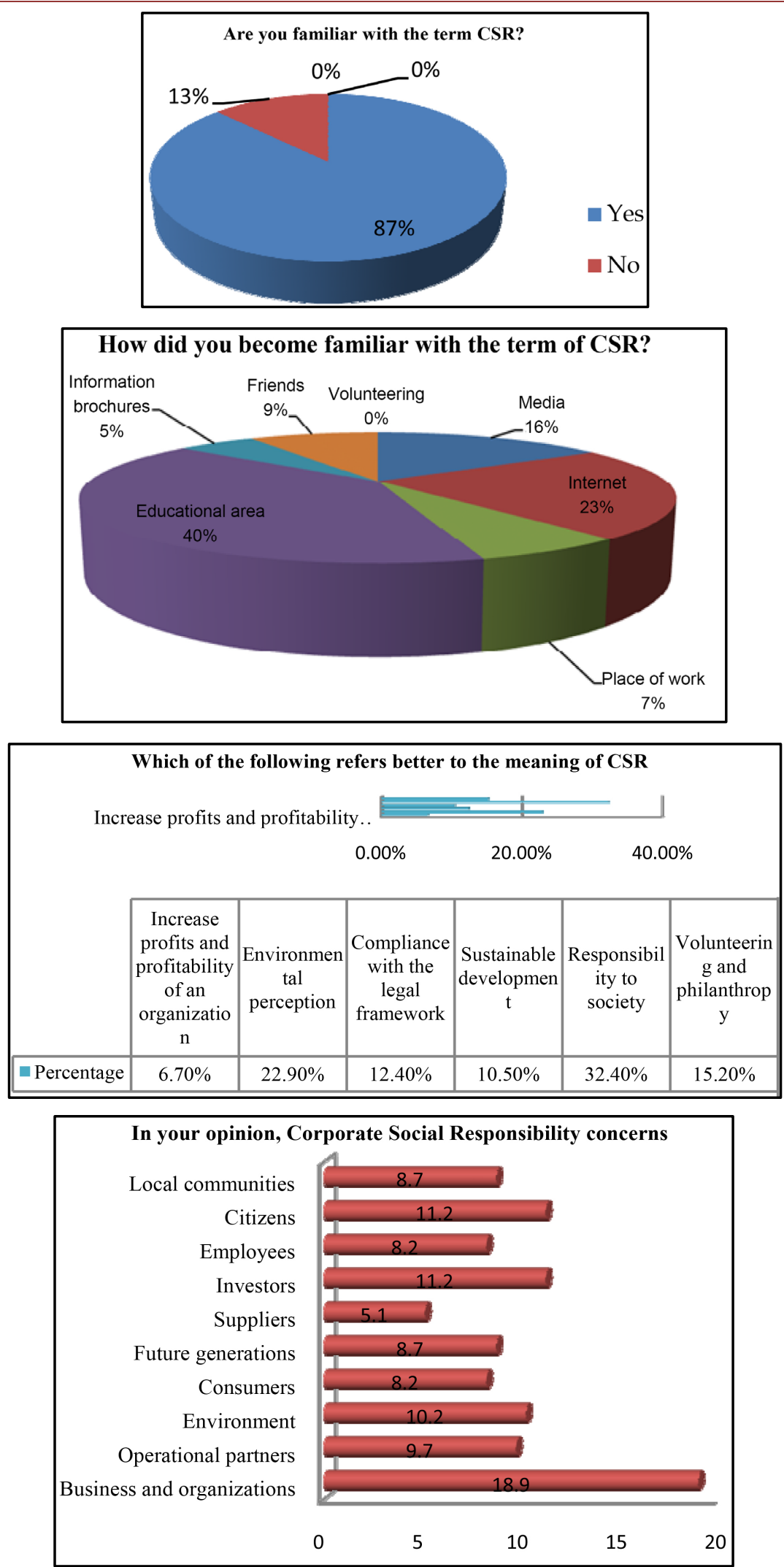


\section{Continued}

Figure 5: To the question, which aspects does CSR include, $23.5 \%$ claimed Social and $19.6 \%$ Environmental aspects.

Figure 6: Regarding the reasons for implementing CSR, the answers were mainly focused on the improvement of corporate reputation and good "image".

Figure 7: Answering the question, why CSR concerns students personally, nearly half of them $(43 \%)$ answered that as future managers and employees, they should have sensitivity to social and environmental issues.
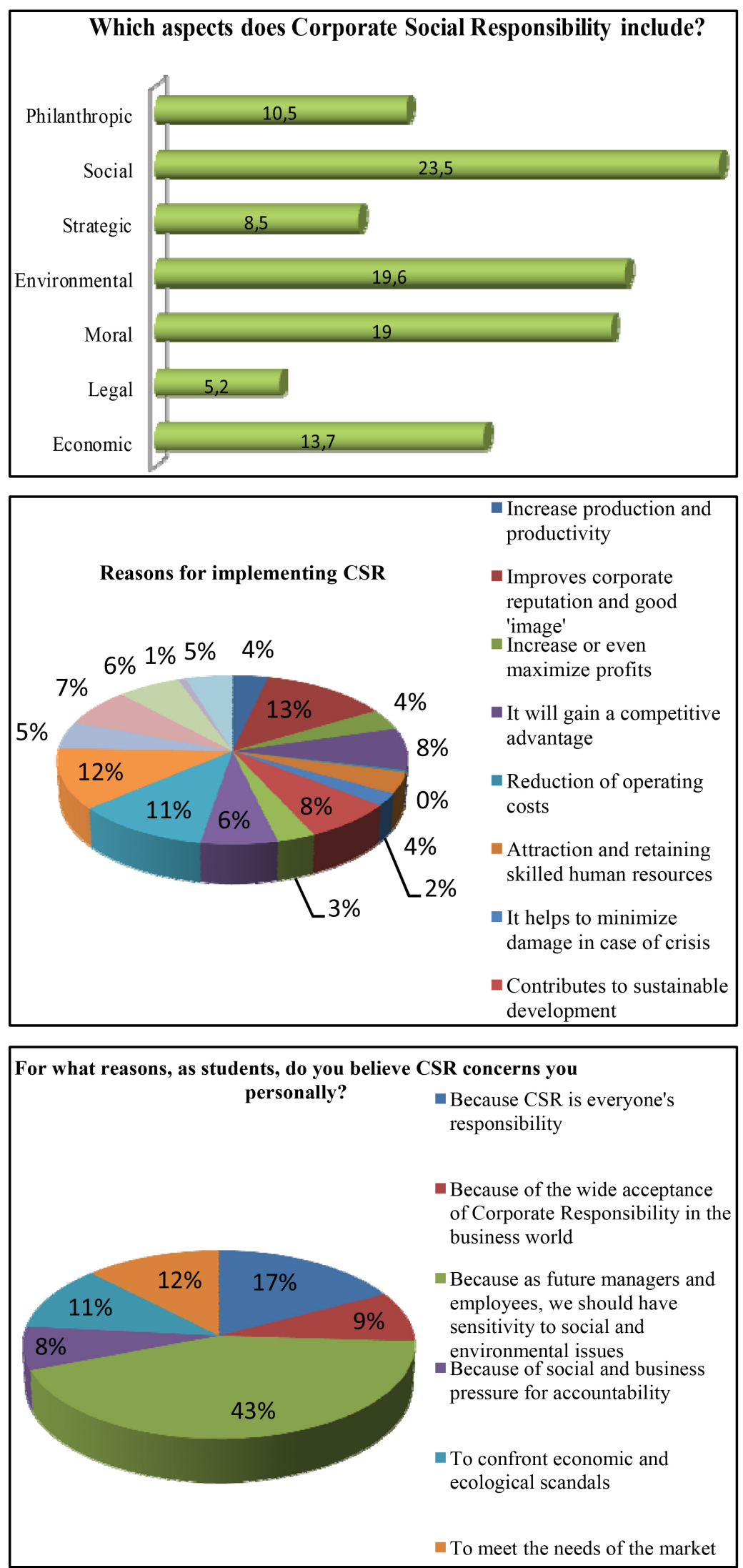
Figure 8: To the question, in which ways can Higher education institutions change the students' philosophy on CSR, they suggested mainly the introduction of CSR courses in the curriculum and secondly the implementation of environmental management and the presentation of events and actions to protect the environment.

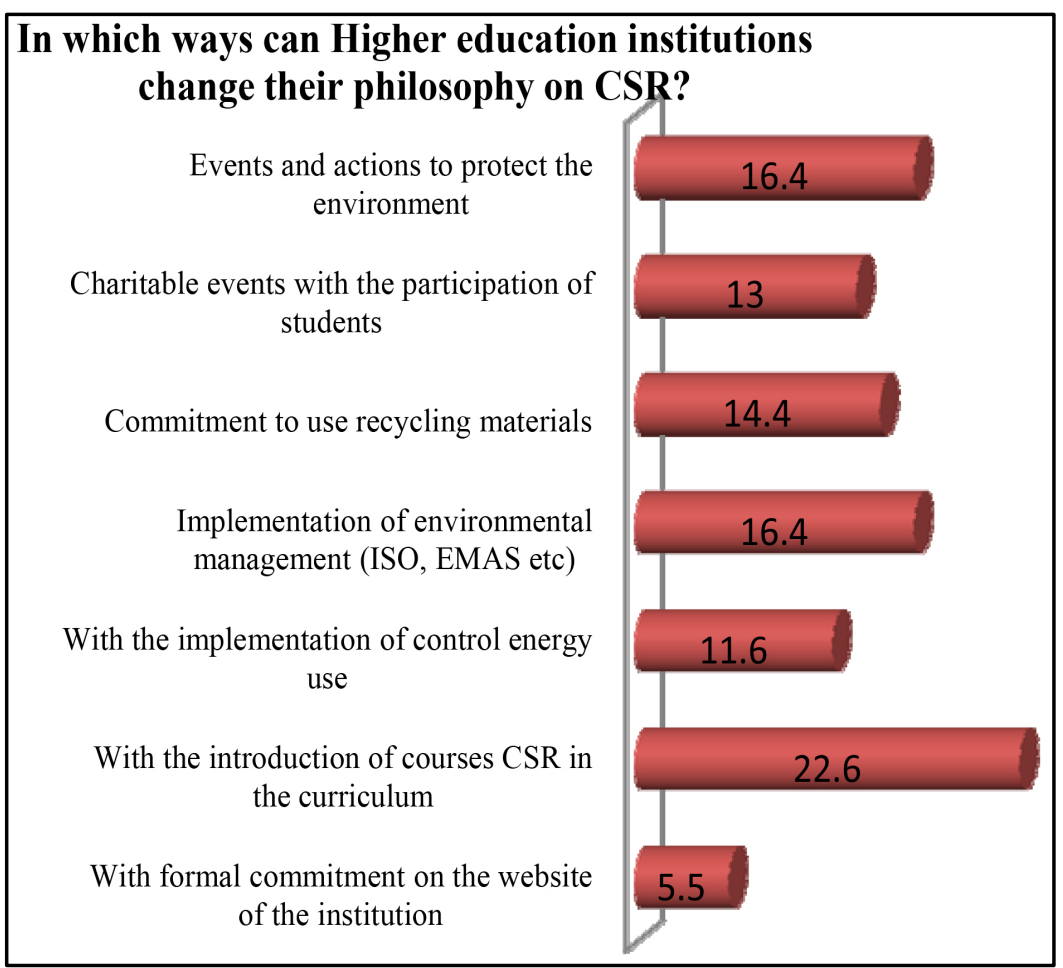

for their academic and professional development in the social and environmental issues and 43\% supports that CSR courses have helped them in the development of responsible behavior as future managers. Therefore, it is observed that CSR, which has been taught in the Greeks universities is a philosophy, which emphasizes on the responsibility towards the society and on the environmental protection and contributes to Sustainable Development. In addition, students were asked why CSR concerns them and responded that as future CEOs or employees, CSR could be useful and very important in the future business market for: 1) future business operation; and 2) social reputation of companies; 3) future human resources; 4) social sensitivity and environmental issues. Finally, students were asked to give their personal opinions and proposals on how Greek Higher Education Institutions can contribute to environmental protection. The main recommendations that were made is the introduction of CSR courses in the curriculum, so that academic citizens will shape a proper perception towards CSR and also this perception will be transmitted to academic staff and professors in order to, gradually, integrate the new philosophy in order to be applied by HEIs operations. Moreover, students consider that HEI should implement control energy use, as well as the implementation of environmental management systems (ISO, EMAS, etc.). An additional recommendation is the commitment of HEIs for recycling and the use of recycled materials in every activity. Furthermore, students suggest the planning of informative events and actions for the protection and restoration of the environment (volunteering, planting, etc.) in- 
side their university so as to inform the academic society about the eco-friendly policies. According to the sample, these recommendations will greatly contribute to the integration and adoption of CSR-oriented and environmentally friendly behaviors across the academic community in collaboration with the business community (Sepetis \& Rizos, 2014). Nikolaidis \& Efthymiadis (2016) concluded that students should not only take courses about CSR, but they should become more actively involved in various CSR activities. Companies could play a significant role at this point, by allowing students to participate in their CSR initiatives. In Greece, despite some initial progress, there is still a long way to go as far as CSR educational programs are concerned (Nikolaidis \& Efthymiadis, 2016). Pitoska et al. (2018), analyze the dominant perceptions of stakeholders towards CSR in HEIs, a qualitative empirical research, which was conducted in the region of Northern Greece, via online structured questionnaires. Their results demonstrated that there are differences in CSR perception and understanding among the surveyed stakeholders. It is worth noting that the majority of the participants were aware of the actual meaning and purpose of CSR, as well as of the potential benefits from its implementation. Most of the stakeholders considered CSR as a contemporary concept, related to environmental and social aspects, company profitability, legislative framework, voluntary work and charity as well as sustainable development. In addition, the research highlighted that it is vital that Greek HEIs incorporate CSR or business ethics in their curricula (Pitoska et al., 2018).

Finally, the Greek research's in the Greek Education for the Sustainable Development and CSR and recent relevant research's for Leal Filho and Lozano and co-authors confirm the hypothesis of Walker and co-authors that "there are strong parallels between the CSR orientation of Greek students and students and managers in other countries". According to the international research in the field of Higher Education for Sustainable Development by the Leal Filho, and to other researchers in a 2017 explorative study about the fundamental obstacles to implementing sustainability at universities there have been successful developments in the field of Higher Education for Sustainable Development over the past 15 years or so and there are still numerous challenges to overcome. Among these challenges is the need for Higher Education Institutions to improve the integration of sustainability in the curriculum and in research, and most important, to integrate it holistically in their systems (Leal Filho et al., 2017, 2018). In the same research field, a paper that focuses in the European Universities by Lozano et al. (2019) suggests that although there has been considerable progress in the incorporation of Sustainable Development into the curricula of higher education institutions (HEIs) in Europe, particularly on competences for sustainable development and on pedagogical approaches, there has been limited research though on the connection between how courses are delivered (pedagogical approaches) and how they may affect sustainability competences (Lozano et al., 2015, 2019). 


\section{Conclusion}

HEIs staff in Greek Universities and especially professors should provide students, not only with the skills and training they will need in their future business careers, but they should also make them understand how crucial and vital decision making in social, environmental and corporate governance issues within an organization is. Every wrong and right decision has an impact. Greek students will be future managers, CEOs and future employees and will be responsible for the shaping of business principles, values, policies and strategies, which should be sustainable, socially, ethically and environmentally responsible.

From the business side, since 2000, research has shown the growing desire of international and Greek students to incorporate CSR into university education in collaboration with the business community. In addition, many researchers point out that the promotion of such educational programs requires the requisite demand from companies and civil society organizations to develop an ethical awareness in education. Therefore, the Greek Business Schools supporting Sustainable Development Goals and CSR will have a strong interest in further collaborating with the business community in a number of ways, summarized:

- Collaboration with companies for the training of students in CSR business practice;

- Develop SDG-related exchange programs between universities and businesses;

- Develop "proof-of-concept" SDG solutions for take-up by business;

- Arrange innovation challenges to address the SDGs for researchers across the university and external stakeholders;

- Encourage processes to assess the impacts of proposed solutions on all other SDGs and seek to maximize co-benefits and minimize negative impacts;

- Development of researches on SDGs and CSR in small and medium sized companies;

- Development of educational tolls for lifelong learning and e-learning in business ethics, on SDGs;

- Development of operational tools of sustainable development, such as environmental accounting and social accountability reports (CSR index, GRI reports);

- Development of partnerships for the implementation of quality systems and environmental or social management and corporate governance issues (ESG).

- Collaborate with businesses' community to develop new technologies and solutions to address the SDGs;

- Establish innovation hubs focused on SDG-related challenges, partnering businesses and university based research;

- Incubate start-up high-tech companies associated with university research programs inspired by the SDGs and evaluated by their contribution to the SDGs.

A major recommendation in the field of Higher Education Institutions for Sustainable Development and CSR strategies is that universities should establish 
formal structures to guide the implementation of social, environmental and corporate governance management in the operational level of the university. Moreover, sustainable development policies and CSR programs, in Greek Universities, specifically in Business Schools should be supported with specific academic personnel, instead of trying to pursue them on an ad hoc with current academic staff basis, as is seen in many cases. In addition, the areas of CSR management and the integration of sustainable development goals into the business community are major obstacles in a day-to-day business operational management. For this reason, we follow the lack of interest of companies in the issue of CSR or their concern for sustainable development issues. The lack of business structures, such as the social and environmental sector in companies responsible for ESG issues (for instance GRI reports) also contributes to the problem of SDGs in the Greek business community. To achieve these goals, today's most of the Greek companies plan training programs with business consultancies and other NGO organizations, which usually prepare their employees in order to assist with the implementation of the aims of the corporate social responsibility, environmental policy and corporate governance issues. On the contrary, in this paper we support that sustainable development education and CSR programs should be incorporated into Greek university business schools and should be supported by the Greek business community and educate future CEOs and employees on Sustainable Development Goals.

\section{Acknowledgements}

This study has been done within the framework of the Postgraduate Health and Social Care Management Programme of the University of West Attica.

\section{Conflicts of Interest}

The authors declare no conflicts of interest regarding the publication of this paper.

\section{References}

Aleixo, A. M., Leal, S., \& Azeiteiro, U. M. (2018). Conceptualization of Sustainable Higher Education Institutions, Roles, Barriers, and Challenges for Sustainability: An Exploratory Study in Portugal. Journal of Cleaner Production, 172, 1664-1673. https://doi.org/10.1016/j.jclepro.2016.11.010

Anderberg, E. L., Norden, B., \& Hansson, B. (2009). Global Learning for Sustainable Development in Higher Education: Recent Trends and a Critique. International Journal of Sustainability in Higher Education, 10, 368-378. https://doi.org/10.1108/14676370910990710

Benn, S., \& Kramar, R. (2011). Educating for Sustainability and CSR: What Is the Role of Business Schools? Special Issue of Journal of Management \& Organization, 17, 128. https://doi.org/10.1017/S1833367200001310

Benn, S., \& Rusinko, C. (2011). The Technological Community as a Framework for Educating for Sustainability in Business Schools. Journal of Management \& Organization 
Special Issue of Educating for Sustainability and CSR: What Is the Role of Business Schools, 17, 656-669. https://doi.org/10.1017/S1833367200001310

Cantalapiedra, I. R., Bosch, M., \& López, F. (2006). Involvement of Final Architecture Diploma Projects in the Analysis of the UPC Buildings Energy Performance as a Way of Teaching Practical Sustainability. Journal of Cleaner Production, 14, 958-962. https://doi.org/10.1016/j.jclepro.2005.11.040

Ceulemans, K., Prins, D. M., Cappuyns, V., \& Coninck, D. W. (2011). Integration of Sustainable Development in Higher Education's Curricula of Applied Economics: Large Scale Assessments, Integration Strategies and Barriers. Journal of Management \& Organization Special Issue of Educating for Sustainability and CSR: What Is the Role of Business Schools, 17, 621-640. https://doi.org/10.5172/jmo.2011.622

Christensen, L. J., Pierce, E., Hartman, L. P., Hoffman, W. M., \& Carrier, J. (2007). Ethics, CSR, and Sustainability Education in the Financial Times Top 50 Global Business Schools: Baseline Data and Future Research Directions. Journal of Business Ethics, 73, 347-368. https://doi.org/10.1007/s10551-006-9211-5

Cowton, C. J., \& Cummins, J. (2003). Teaching Business Ethics in UK Higher Education: Progress and Prospects. Teaching Business Ethics, 7, 37-54. https://doi.org/10.1023/A:1022665221990

Cummins, J. (1999). The Teaching of Business Ethics at Undergraduate, Postgraduate and Professional Levels in the UK.

Deale, C., Nichols, J., \& Jacques, P. (2009). A Descriptive Study of Sustainability Education in the Hospitality Curriculum. Journal of Hospitality \& Tourism Education, 21, 34-42. https://doi.org/10.1080/10963758.2009.10696958

Dlouhá, J., Henderson, L., Kapitulcinova, D., \& Mader, C. (2018). Sustainability-Oriented Higher Education Networks: Characteristics and Achievements in the Context of the UN DESD. Journal of Cleaner Production, 172, 4263-4276.

https://doi.org/10.1016/j.jclepro.2017.07.239

Down, L. (2006). Addressing the Challenges of Mainstreaming Education for Sustainable Development in Higher Education. International Journal of Sustainability in Higher Education, 7, 390-399. https://doi.org/10.1016/j.jclepro.2017.07.239

Elliott, H., \& Wright, T. (2013). Barriers to Sustainable Universities and Ways forward: A Canadian Students' Perspective. The 3rd World Sustainability Forum.

https://www.researchgate.net/publication/269203082 https://doi.org/10.3390/wsf3-f006

Fien, J. (2002). Advancing Sustainability in Higher Education. International Journal of Sustainability in Higher Education, 3, 243-253. https://doi.org/10.1108/14676370210434705

Global University Network for Innovation (GUNi) (2017). Higher Education in the World: Towards a Socially Responsible University: Balancing the Global with the Local. http://www.guninetwork.org/files/download_full_report.pdf

Global University Network for Innovation (GUNi) (2018). Implementing the 2030 Agenda at Higher Education Institutions: Challenges and Responses. http://www.guninetwork.org/files/guni_publication_-_implementing_the_2030_agend a_at_higher_education_institutions_challenges_and_responses.pdf

Grindsted, S. T. (2011). Sustainable Universities: From Declarations on Sustainability in Higher Education to National Law. Environmental Economics, 2, 29-36. https://doi.org/10.2139/ssrn.2697465

Hartman, L., \& Hartman, E. (2005). How to Teach Ethics: Assumptions and Arguments. 
Journal of Business Ethics Education, 1, 165-212.

https://doi.org/10.5840/jbee20041212

Hoover, E., \& Harder, M. K. (2014). What Lies beneath the Surface? The Hidden Complexities of Organizational Change for Sustainability in Higher Education. Journal of Cleaner Production, 106, 175-188. https://doi.org/10.1016/j.jclepro.2014.01.081

Huckle, J. (1999). Locating Environmental Education between Modern Capitalism and Postmodern Socialism. Canadian Journal of Environmental Education, 4, 36-45.

Idowu, O. (2008). An Empirical Study of What Institutions of Higher Education in the UK Consider to Be Their Corporate Social Responsibility. In K. Aravossis, C. A. Brebbia, \& N. Gomez (Eds.), Environmental Economics and Investment (pp. 263-273). Berlin: Springer. https://doi.org/10.2495/EEIA080261

Karatzoglou, B. (2013). An in-Depth Literature Review of the Evolving Roles and Contributions of Universities to Education for Sustainable Development. Journal of Cleaner Production, 49, 44-53. https://doi.org/10.1016/j.jclepro.2012.07.043

Leal Filho, W., Jim Wu, Y. C., Londero, L., Veiga, L., Azeiteiro, U. M., Caeiro, S., \& da Rosa Gama Madruga, L. R. (2017). Identifying and Overcoming Obstacles to the Implementation of Sustainable Development at Universities. Journal of Integrative Environmental Sciences, 14, 93-108. https://doi.org/10.1080/1943815X.2017.1362007

Leal Filho, W., Londero, L., Becker, D., Skanavis, C., Kounani, A., Sardi, C., Papaioannidou, D. et al. (2018). Sustainable Development Policies as Indicators and Pre-Conditions for Sustainability Efforts at Universities: Fact or Fiction? International Journal of Sustainability in Higher Education, 19, 85-113.

https://doi.org/10.1108/IJSHE-01-2017-0002

Lindroos, P. (2001). Baltic Agenda 21 Education: Preliminary Report. Geneva: UN

Lourdel, N., Gondran, N., Laforest, V., Debray, B., \& Brodhag, C. (2007). Sustainable Development Cognitive Map: A New Method of Evaluating Student Understanding. International Journal of Sustainability in Higher Education, 8, 170-182. https://doi.org/10.1108/14676370710726634

Lozano, R., Barreiro-Gen, M., Lozano, J. F., \& Sammalisto, K. (2019) Teaching Sustainability in European Higher Education Institutions: Assessing the Connections between Competences and Pedagogical Approaches. Sustainability, 11, 1602.

https://doi.org/10.3390/su11061602

Lozano, R., Ceulemans, K., Alonso-Almeida, M., Huisingh, D., Lozano, F. J., Waas, T., Lambrechts, W., Lukman, R., \& Hugé, J. (2015). A Review of Commitment and Implementation of Sustainable Development in Higher Education: Results from a Worldwide Survey. Journal of Cleaner Production, 108, 1-18.

https://doi.org/10.1016/j.jclepro.2014.09.048

Macris, A., \& Georgakellos, D. (2006). A New Teaching Tool in Education for Sustainable Development: Ontology-Based Knowledge Networks for Environmental Training. Journal of Cleaner Production, 14, 855-867. https://doi.org/10.1016/j.jclepro.2005.12.009

Mahoney, J. (1990). Teaching Business Ethics in the UK, Europe, and the USA: A Comparative Study.

Manoliadis, O. (2009). Education for Sustainability: Experiences from Greece. Journal of Professional Issues in Engineering Education and Practice, 135, 70-74. https://doi.org/10.1061/(ASCE)1052-3928(2009)135:2(70)

Moon, J., \& Matten, D. (2004). Corporate Social Responsibility Education Europe. Journal of Business Ethics, 54, 323-337. https://doi.org/10.1007/s10551-004-1822-0 
Moon, J., \& Orlitzky, M. (2011). Corporate Social Responsibility and Sustainability Education: A Trans-Atlantic Comparison. Journal of Management \& Organization Special Issue of Educating for Sustainability and CSR: What Is the Role of Business Schools, 17, 583-563. https://doi.org/10.1007/s10551-004-1822-0

Nejati, M., Shafaei, A. Z., Salamzadeh, Y., \& Daraei, M. (2011). Corporate Social Responsibility and Universities: A Study of Top 10 World Universities' Websites. African Journal of Business Management, 5, 440-447.

Nikolaidis, Y., \& Efthymiadis, G. (2016) Education on Corporate Social Responsibility in Greece: Is There Any and Does It Affect Students' Perception? Book Chapter in Social Responsibility Education across Europe A Comparative Approach. Berlin: Springer. https://doi.org/10.1007/978-3-319-26716-6_8

Niu, D., Jiang, D., \& Li, F. (2010). Higher Education for Sustainable Development in China. International Journal of Sustainability in Higher Education, 11, 153-162. https://doi.org/10.1108/14676371011031874

Pitoska, E., Katarachia, A., \& Giannakis, K. (2018). Corporate Social Responsibility in Greek Higher Educational Institutions. Corporate Governance and Organizational Behavior Review, 2, 31-39. https://doi.org/10.22495/cgobr_v2_i1_p3

Posch, A., \& Steiner, G. (2006). Integrating Research and Teaching on Innovation for Sustainable Development. International Journal of Sustainability in Higher Education, 7, 243-253. https://doi.org/10.1108/14676370610677847

Ramos, T. B., Caeiro, S., van Hoof, B., Lozano, R., Huisingh, D., \& Ceulemans, K. (2015). Experiences from the Implementation of Sustainable Development in Higher Education Institutions: Environmental Management for Sustainable Universities. Journal of Cleaner Production, 106, 3-10. https://doi.org/10.1016/j.jclepro.2015.05.110

Rossouw, D. (2002). Three Approaches to Teaching Business Ethics. Teaching Business Ethics, 6, 411-433. https://doi.org/10.1023/A:1021159310821

Rusinko, C. A. (2010). Integrating Sustainability in Higher Education: A Generic Matrix. International Journal of Sustainability in Higher Education, 11, 250-259. https://doi.org/10.1108/14676371011058541

Sepetis, A., \& Rizos, F. (2011). Sustainable Development and Corporate Social Responsibility in Higher Education: Some Evidence from Greece. Kos, Greece: International Conference on Integrated Information.

Sepetis, A., \& Rizos, F. (2014). Corporate Social Responsibility and Environmental Management Policies in Higher Education. Volos: ENVECON 2014 1st Panhellenic Conference Panhellenic Conference on Economics of Natural Resourcesand the Environment: Climate Change.

Setó-Pamies, D., Domingo-Vernis, M., \& Rabassa-Figueras, N. (2011). Corporate Social Responsibility in Management Education: Current Status in Spanish Universities. Journal of Management \&Organization Special Issue of Educating for Sustainability and CSR: What Is the Role of Business Schools, 17, 604-620. https://doi.org/10.1017/S1833367200001280

Shannon, J. R., \& Berl, R. L. (1997). Are We Teaching Ethics in Marketing? A Survey of Students' Attitudes and Perceptions. Journal of Business Ethics, 16, 1059-1075. https://doi.org/10.1023/A:1017922005651

Sims, R. R., \& Felton, E. L. (2006). Designing and Delivering Business Ethics Teaching and Learning. Journal of Business Ethics, 63, 297-312. https://doi.org/10.1007/s10551-005-3562-1

Stubbs, W., \& Schapper, J. (2011). Two Approaches to Curriculum Development for 
Educating for Sustainability and CSR. International Journal of Sustainability in Higher Education, 12, 259-268. https://doi.org/10.1108/14676371111148045

UNESCO (2018a). Education for Sustainable Development Goals Learning Objectives. https://unesdoc.unesco.org/ark:/48223/pf0000247444

UNESCO (2018b). GREECE Implementation of the UNECE Strategy for Education for Sustainable Development.

https://www.unece.org/fileadmin/DAM/env/esd/Implementation/NIR_2018/Preface_fi nal_GR.pdf

Van Luijk, H. J. L. (2001). Business Ethics in Europe: A Tale of Two Efforts. In R. Frederick (Ed.), A Companion to Business Ethics. Berlin: Springer.

Verhulst, E., \& Lambrechts, W. (2015). Fostering the Incorporation of Sustainable Development in Higher Education. Lessons Learned from a Change Management Perspective. Journal of Cleaner Production, 106, 189-204.

https://doi.org/10.1016/j.jclepro.2014.09.049

Walker, R., Kanellopoulos, C., Papanayiotou, M., \& Vitalis, A. (2003). An Investigation of CSR Orientations among Greek University Students. European Research Studies, 6, 51-64.

Weber J. (1990). Measuring the Impact of Teaching Ethics to Future Managers. Journal of Business Ethics, 9, 183-190. https://doi.org/10.1007/BF00382643

Wheeler, D., Horvath, D., \& Victor, P. (2001). Graduate Learning for Business and Sustainability. Journal of Business Administration and Policy Analysis, 27-29, 167-187.

Wright, J. (2003). Introducing Sustainability into the Architecture Curriculum in the United States. International Journal of Sustainability in Higher Education, 4, 100-105. https://doi.org/10.1108/14676370310467131

Wright, T. (2002). Definitions and Frameworks for Environmental Sustainability in Higher Education. International Journal of Sustainability in Higher Education, 3, 203-220.

https://doi.org/10.1108/14676370210434679 